\title{
Vulnerability and Resilience of Niger Delta Coastal Communities to Flooding.
}

\author{
Prince C. Mmom and Aifesehi, Pedro E.E \\ Ph.D., REM, MNES ,Centre for Disaster Risk Management \& Development Studies, Department of Geography \\ \& Environmental Management, University of Port Harcourt, P.M.B 5323,Choba, Port Harcourt.
}

\begin{abstract}
Flooding is a natural phenomenon and like other environmental events, the Niger Delta people have in the past adapted to flood events. However over the years, landusel land cover change and poor landuse planning have exacerbated the impact of flood disasters. This paper which focuses on the vulnerability to flood hazard of Riverine communities in the Niger Delta, Nigeria, explores the capacity of communities to live with or cope with floods. Their adaptations to changes in flood regimes (resilience) will depend on several factors: political, economic, ecological (human modification to flood plains), sociocultural factors. The data generated from the fieldwork showed a power struggle between culture and the dominant hazard management paradigm. This study puts a human face on natural disaster and looked at the issue of flooding from the experiences of the communities. The findings showed that some residents of the communities are resilient, while others are passive and are more vulnerable to floods. However, branding or christening any individual or group as either vulnerable or resilient would be nonsensical as people can be both resilient and vulnerable at the same time therefore, policy makers need to build on the strengths, rather than focus on the weaknesses and on offering emergency relief.
\end{abstract}

Key Words: Flooding, Landuse, Niger Delta, Hazard, Natural disaster, vulnerability, resilience

\section{Introduction:}

Disaster risk is an ever-increasing global problem, and hydro-meteorological events make up the majority of disaster events (United Nations 2007). A review of international literature on flood studies revealed important insights as to how communities subject to flooding operate. More is currently known about the extremely complex and uncertain nature of the hydrometeorology of floods (Brilly and Polic 2005) and its technical aspects than about people's behaviour (Montez and Gruntfest, 2002). Researchers have emphasized the importance of studying people's behaviour, information needs, experiences and lessons learned from past events. In the case of the developing countries, Niger Delta, Nigeria is considered as one of the most vulnerable to the effects of climate change (Mmom, 2010). In the Niger Delta, these effects are increasingly evident in the form of higher temperatures, heavy and prolonged rainfall and the resultant floods and shoreline erosion. During the last twenty years, especially the immediate past year (2012), floods in the Niger Delta have accounted for $39 \%$ of total natural hazards /disaster that cost the Niger Delta communities, on average, in excess of $\$ 300,000,000$ loss (Chukwu-Okeah, 2012). Flooding is a natural phenomenon, and the people of the Niger Delta (located in South-South of Nigeria (see Figures 1) have experienced it almost every year with varying degrees of severity.

Floods are acts of God, but flood losses are largely acts of man. Human encroachment upon the floodplains of rivers accounts for the high annual total of flood losses (White, 1945:2).

Thus this paper focuses on the vulnerability and the level of resilience among the members of the Local communities who live along the coastline in the region (see Figure 2 ). They have survived floods but their homes and livelihoods are affected for many months of each year. The communities seem to have been largely ignored, marginalized and excluded from the planning process and emergency responses. However, more frequent and severe disaster events such as floods are placing greater strain on the resources and funding of the various levels of Government and the Emergency Management Agencies in Nigeria. Hence it is imperative to gain a detailed understanding about how communities at risk can adapt and what their vulnerabilities, resilience and adaptive capacities are. Against the foregoing backdrop, certain fundamental questions arise: What is the extent of vulnerability of these riverine communities to annual flooding in the region? What are the factors that cause these communities to be vulnerable to floods? How have the communities responded to floods in the past? How resilient are they to flooding? Have the communities' characteristics and its geographical location contributed to greater to their vulnerability or have these factors contributed to their resilience to floods?

Answers to these questions form the focus of this paper. The vulnerability approach established by Wisner, et'al (2004) were used to examine the effect that the annual flooding of the region has had on the communities. The 
work on flooding carried out by Burton, et'al (1978 and 1993) were applied to the data collected to evaluate the range of the communities' responses to flood.

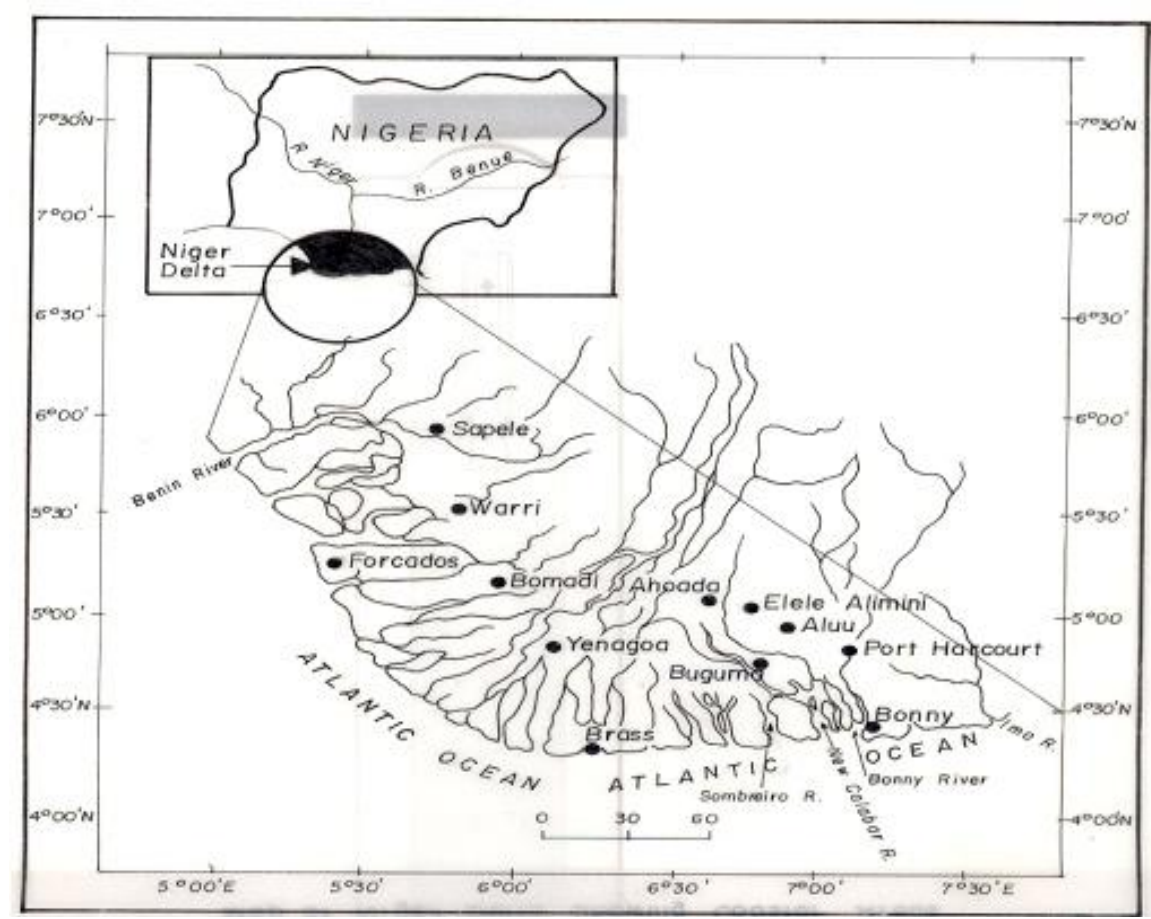

Fig: 1 Map of the Niger Delta showing the sampled coastal communities.

\section{Theoretical Background}

Natural hazard theories provide the essential principles for discussing the importance of vulnerability at the community level in relation to flood management. This paper presents a strong argument for the need to seriously consider the social aspect of natural hazards guided by vulnerability theory established by Wisner, et' al. (2004). This section outlines the theory which explains the conditions that underpin the vulnerability experienced by the Niger Delta Communities during annual floods. The main concept of vulnerability used in this paper is based on the work of Blaikie, et al. (1994) and Wisner et al. (2004) who use the concept of vulnerability to understand what causes natural disasters and how to reduce the impacts. In fact, their general focus was on understanding the ways in which social systems operate to generate disasters by making people vulnerable (Thanahathai,S, 2008).

\section{Paradigms of Hazard- Dominant and the behavioural}

The three main approaches to natural hazard theory in the social sciences are currently identified as the dominant approach, the behavioural approach, and the structural approach (Smith, 1992).However for the purpose of this discourse, emphasis is placed on the Dominant and the behavioural paradigms. In the dominant technocratic view, the blame was assumed to lie with nature hence it appeared logical that the control, monitoring and prediction of natural events would provide an effective solution. In the dominant paradigm, there is high level of reliance on field monitoring and scientific explanation of geophysical processes. The most important goal in relation to hazards is to predict extreme events. Also, there is much emphasis on mechanical and managerial control aiming to physically rearrange human activities in accordance with the objectives, geophysical patterns and probabilities. The aim is to contain nature through environmental engineering works which include zoning, building codes and 'fail-safe' structures such as flood embankment (Thanahathai, 2008).

Another important area is the formulation of disaster plans and emergency measures. Action is most commonly put in the hand of military-style organizations as it underpins the notion of state re-imposing order on a devastated community. Hillhorst (2003) stated that the domain of international science and disaster management is dominated by a hazard-centred paradigm. This paradigm is embedded in a capitalist discourse where nature and society are seen as separate and in which nature is seen as a commodity that can be utilized and controlled through expert knowledge and modern administration (Escobar, 1999). Disaster management is predominantly focused on the physical processes considered to underlie disaster and is geared to developing technology for monitoring and predicting these processes. Thus the aim is to contain nature through engineering works such as flood embankments or dams (Thanahathai, 2008). 


\section{Behavioural Approach}

The behavioural approach looks at ways people can avoid disasters by modifying behaviour. Thus, modifying human behaviour, particularly locational decision making would reduce hazards. Burton, Kates and White (1978) used a systems approach to explain how humans responded to hazards and focused on the interactions of humans with their environment as well as the natural events that occurred within that environment. Thanahathai (2008) noted that their work on natural hazards mainly focused on the floods occurring in the United States at the time. Nevertheless, despite the lapse of time, their views could still be applicable in flood hazard management in contemporary times. The human ecology approach to natural hazards identifies the following ranges of responses: modify the event, modify human use, and modify losses: the traditional responses such as building flood embankments and funding relief concentrated on modification of the event and losses. This is illustrated in Figure 7 which shows the different foci of the two approaches (Burton et al., 1978)

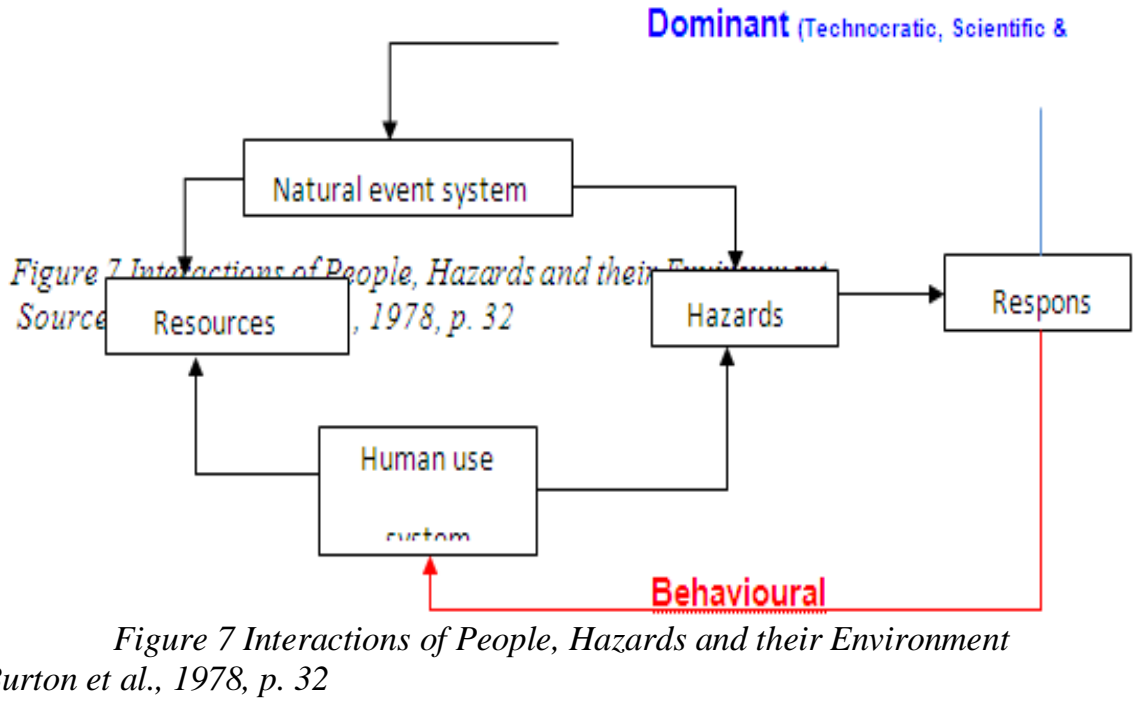

Source: After Burton et al., 1978, p. 32

The focus of the dominant paradigm was on modifying the natural events systems whereas the behavioural approach sought to modify the human use system. This was a considerable advance upon the dominant paradigm bringing attention to the role people play in creating hazards. More so the dominant paradigm is criticized failing to provide a "social theory capable of addressing social process (Watts, 1983 and Thanahathai, 2008). The behavioural view has been criticized because of its over-exaggeration of the role of individuals, either as decision-maker or as victim (Smith, 1992). From a political economic perspective, the notion of individual choice is highly problematic as social, political and economic structures constrain an individual's ability to locate wherever they wish for example (Thanahathai, 2008).

\section{The Study Area (Niger Delta)}

The Niger Delta is described as a unique ecological zone by virtue of its size and geophysical configuration (Mmom, 2003). It is one of the world's largest wetlands covering an area of approximately 70,000 $\mathrm{km} 2$, located in the south-south geopolitical region of Nigeria. It lies between latitude $4^{\circ}$ and $6^{\circ}$ North of the equator and longitude $5^{\circ}$ and $7^{\circ}$ East of Greenwich.

Along the coast, the Niger Delta as shown in Fig. 1, it stretches from the Benin river in the West to Bonny river in East, while in land, it begins a few miles below Aboh at a point where river Niger bifurcates into river Nun and Forcados into the Atlantic West at the South, stretching over 160 miles (Udo, 1975; Iyalla, 2001). The Delta could be described as a prism that was formed by the accumulation of sedimentary deposits transported by rivers Niger and Benue. Within the flood plains, the river splits into six major tidal channels and innumerable smaller outlets. Fluvial sediments are deposited throughout the Delta with sand and silt suspension during both high and low flood regimes. The region experiences very high annual rainfall ranging between 3000 to $4500 \mathrm{~m}$ with double maxima characteristics of July and September peaks. Although the Niger Delta can be roughly categorized into four ecological sub-zones (coastal barrier Islands, mangrove, fresh water swamp forest and the lowland rainforest), the mangrove is the largest and dominant eco-subzone. In terms of socio-economic development, the region could be described as being a "rich region with poor people". It is blessed with abundant Crude Oil and Natural Gas, which is the main stay of Nigeria's economy. Apart from crude oil and natural gas, the mangroves offer a lot of biological resources on which the rural livelihood depend. 


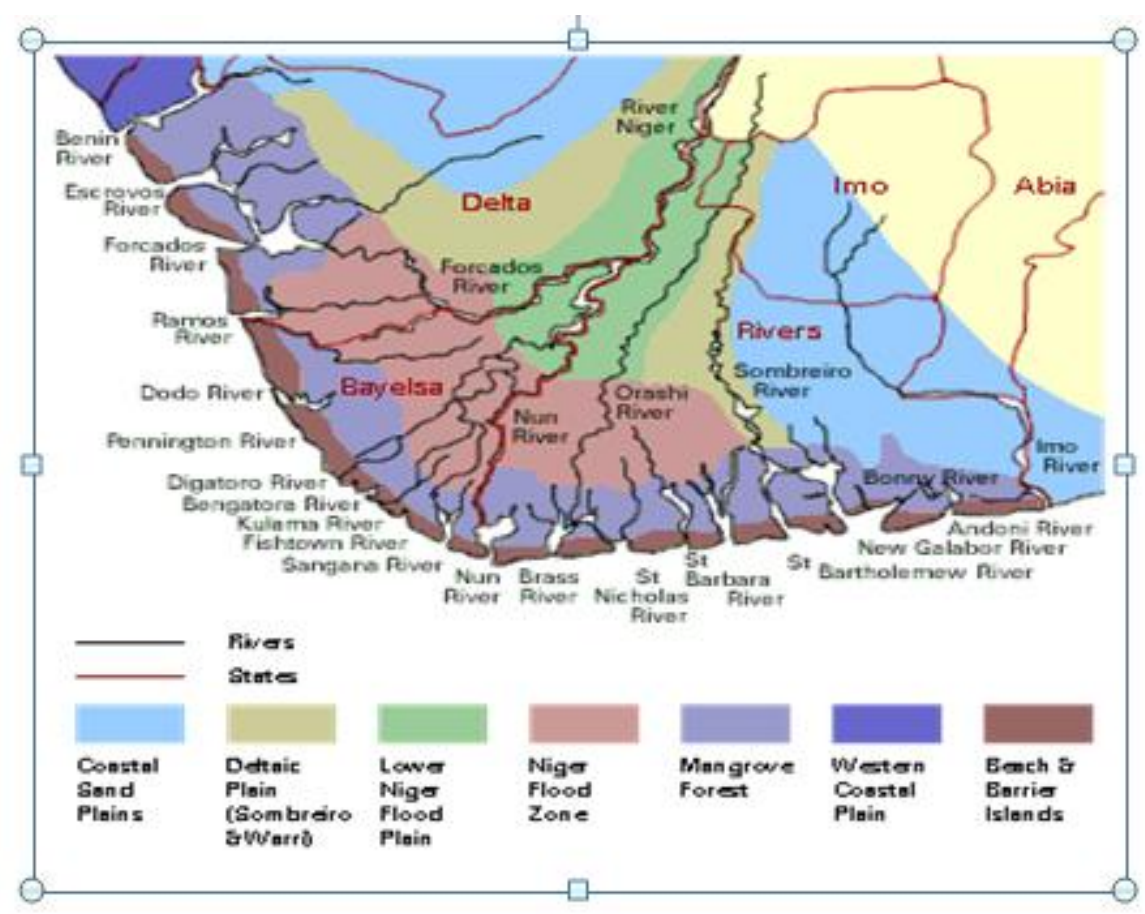

Fig. 2 Map of the Niger Delta showing the various river systems and floodplains.

Before the discovery of crude oil, agriculture was the dominant occupation of the people. Crude oil was discovered in commercial quantity in the region specifically in the present Bayelsa State in 1956 (Omofonmwa and Odia, 2009). Since then oil exploration and exploitation has continued resulting into what is termed environmental destruction due to neglect and less concern of the multinational companies in environmental management in the area. Apart from environmental degradation resulting from Oil \& Gas mining activities, the Niger Delta is plagued with the problem of perennial flooding and shoreline erosion which has accounted severe loss of lives \& properties in the region owing to its physiographic configurations.

The Niger Delta with a population over 10 million people is one of the industrial and commercial hubs of Nigeria. It is the home of Nigeria's Oil and Gas Industries and a commercial nexus in Nigeria because of its coastal location. In fact, it is witnessing rapid economic growth and little or no development.

\section{Methodology/ Data Analysis}

This study focused on reconstructing an event rather than social modeling. Its main aim was to identify the characteristics of a society that is regularly flooded in terms of its vulnerability and resilience. Two types of data were collected, primary data using structured questionnaires and complemented by personal interviews and secondary through literature review process. Five hundred households from ten (10) riverine communities in the Niger Delta region were surveyed. The collected data were analysed using appropriate quantitative and qualitative techniques. Basically, the data were analysed using frequency tables and percentages. Qualitative data were analysed by associating responses and interpretations with sample communities' characteristics in terms of vulnerability and resilience

Table 1: Perceived causes of vulnerability to flood

\begin{tabular}{|l|l|l|l|}
\hline S/N & \multicolumn{1}{|c|}{ Causes } & Frequency & Percent \\
\hline $\mathbf{1}$ & Physical terrain & $\mathbf{4 0 0}$ & $\mathbf{8 8 . 8 \%}$ \\
\hline $\mathbf{2}$ & Heavy amount of rainfall & $\mathbf{4 3 2}$ & $\mathbf{9 6 \%}$ \\
\hline $\mathbf{3}$ & Poor drainage & $\mathbf{1 2 5}$ & $\mathbf{2 7 . 7 \%}$ \\
\hline $\mathbf{4}$ & Poor landuse planning & $\mathbf{2 1 6}$ & $\mathbf{4 8 \%}$ \\
\hline $\mathbf{5}$ & Landuse \& Land cover change & $\mathbf{1 2 1}$ & $\mathbf{2 6 . 8 \%}$ \\
\hline & Total & $\mathbf{4 5 0}$ & \\
\hline
\end{tabular}

Table 1 above shows the perceived cause of flooding in the area and from the analysis, $88 \%$ of the households indicated their physical terrain as a major cause of flood in the area; $96 \%$ indicated heavy amount of rainfall, while $48 \%$ indicated poor landuse planning and $27.7 \& 26.8 \%$ went for poor drainage and landuse change. 
Vulnerability and Resilience of Niger Delta Communities to Flooding.

Table 2: Reason for living in flood prone areas

\begin{tabular}{|l|l|l|l|}
\hline S/N & Reasons & frequency & Percentages \\
\hline & To maintain Family ties & 356 & $79.1 \%$ \\
\hline & Livelihood Opportunities & 284 & $56.4 \%$ \\
\hline & Proximity to Work or business Location & 268 & $59.5 \%$ \\
\hline & Born in the community & 325 & $72.2 \%$ \\
\hline & Low cost of Land \& Housing & 121 & $26.8 \%$ \\
\hline & Accessible social amenities & 24 & $5.3 \%$ \\
\hline
\end{tabular}

Analysis of reason for living in flood prone areas in table 2 above shows that about $79 \%$ of the people live in flood prone areas to maintain family ties; $72 \%$ indicated that it is for the reason that they were born in such areas, while $59 \%$ affirms that it due to proximity to their place of work/business. Also, $56 \%$ prefer living in such areas because of livelihood opportunities there, $26 \%$ said it is for the low cost of land and housing, while about $5 \%$ noted that it is for access to social amenities.

Table 3 Impact of previous floods in the area

\begin{tabular}{|l|l|l|}
\hline Loss of houses & 342 & $76 \%$ \\
\hline Loss of crops/domestic animal & 322 & $71 \%$ \\
\hline Loss of lives & 21 & $4.66 \%$ \\
\hline Loss of properties & 206 & $45.7 \%$ \\
\hline Emotional trauma, stress/ health risk & 264 & 58.66 \\
\hline Destruction of infrastructure & 125 & 27.77 \\
\hline
\end{tabular}

Table 3 above analyses the impact of previous flood in the area. From the table, $76 \%$ lost their houses; $71 \%$ suffered loss of agro-crops and animals; $58 \%$ of them indicated that they suffered stress, emotional trauma as well as some health challenges. About $45 \%$ lost their valuable properties and there were about 21 recorded deaths due to past flood disasters.

Table 4: Willingness of residents to relocate from these flood prone areas

\begin{tabular}{|l|l|l|l|}
\hline S/N & Responses & Frequency & Percentage \\
\hline 1 & Willing to relocate & 126 & $28.6 \%$ \\
\hline 2 & Not willing to relocate & 314 & $71.4 \%$ \\
\hline & Total & 440 & $100 \%$ \\
\hline
\end{tabular}

On the willingness of the people to relocate from the flood prone areas, table 4 above shows despite the impact of the past flood disaster on the people, over $70 \%$ of them are unwilling to relocate their residence, with only about $28 \%$ showing willingness to change their residence.

Table 5 Coping strategies with recent past flood

\begin{tabular}{|l|l|l|}
\hline Raising of building DPC/ heights & 205 & $45.5 \%$ \\
\hline Construction of houses with flexible structures & 231 & $51.3 \%$ \\
\hline Construction of flood diversion trenches & 223 & $49.5 \%$ \\
\hline $\begin{array}{l}\text { Relocation/ Removable of moveable properties to nearest } \\
\text { neighbours }\end{array}$ & 342 & $76 \%$ \\
\hline Early planting/change in farming regime & 286 & $63.5 \%$ \\
\hline
\end{tabular}

Table 5 analyses the coping strategies adopted by the people as a result of the past flood events. From the analysis above, about $45 \%$ of the people raised their Damp Proof Course (DPC) and building heights as an adjustment technique, $51 \%$ constructed their houses with flexible structures; $49 \%$ constructed flood diversion trenches. Furthermore, about $63 \%$ changed their farming regime to early planting, while $76 \%$ relocated and moved their properties to their nearest kits and kin until the flood receded.

Table 6: Where residents were evacuated to during the flood

\begin{tabular}{|l|l|l|l|}
\hline S/N & & Frequency & $\%$ \\
\hline 1 & Family \& friends & 122 & 27.1 \\
\hline 2 & Refugee camp, & 268 & 59.5 \\
\hline 3 & Rented accommodation & 65 & 14.4 \\
\hline
\end{tabular}


During the flood events, government, NGOs and individuals were engaged in flood mitigation. Table 6 above shows that about $27 \%$ of the people relocated to their friends and families in flood free areas; about $14 \%$ moved to rented apartments, while about $59 \%$ were moved to refugee camps in public school buildings.

Table 7: Level of preparedness of households to future flood occurrence

\begin{tabular}{|l|l|l|}
\hline Reponses & Frequency & \% \\
\hline Prepared & 286 & 63.5 \\
\hline Not Prepared & 88 & 19.5 \\
\hline Undecided & 76 & 16.8 \\
\hline Total & $\mathbf{4 5 0}$ & \\
\hline
\end{tabular}

Table 7 above shows the level of preparedness of the residents to future flood hazards and from the table, $63 \%$ of the people indicated that they are ready to face any flood hazards, $19 \%$ are not prepared, while about $16.8 \%$ are undecided.

Table 8: Government and NGOs' interventions during \& after the flood disasters

\begin{tabular}{|l|l|l|}
\hline $\begin{array}{l}\text { Evacuation of residents, provision of relief materials/ } \\
\text { refugees camps }\end{array}$ & Frequency & $\%$ \\
\hline Flood warnings & 238 & 93.3 \\
\hline Enlightenment/ re-orientation & 104 & 52.8 \\
\hline Capital support to victims ( crop seedlings, e.t.c) & 224 & 23.1 \\
\hline
\end{tabular}

Table 8 above describes the intervention by government and non-governmental agencies during and after the flood disaster. About 93\% affirmed that government and other agencies not only evacuated residents, but provided camps and relief materials to flood victims. Similarly, about 52\% affirmed that even before the floods, government agencies, like Nigerian Meteorological Agency (NIMET) gave early warnings of floods, even though many never took them serious.

About $49 \%$ noted that government provided capital support to victims in the forms of crop seedlings, cassava stems, and many more, whereas, about $23 \%$ indicated that government provided counseling, enlightenment and reorientation to flood victims.

\section{Discussion of Results}

A major vulnerability of the riverine communities was the absence of flood household insurance cover. Most of the residents are rarely aware of the possibility of insuring their property against flood losses and even for those who are aware, this insurance is difficult and expensive to obtain, making them more vulnerable to economic losses in flood events. Some residents mistakenly believed their household contents insurance covered them for flood damage, whereas this was frequently not the case. Many homes are located close to the river banks thereby making them vulnerable to flooding. Almost two-third of the residents believe that floods could pose quite a great deal of threat to daily activities. Most of the residents believe a damaging flood could occur in the future and however, they are neither willing to relocate their residence nor seek for insurance cover.

On the other hand, resilient communities must be able to demonstrate the ability to buffer the event, self-organise themselves before, during and after, and adapt and learn from the event. Residents who have lived for a number of years in a community who have a strong sense of belonging and community and feel confident about the capabilities and organizational ability of their institutions are likely to have high levels of resilience and well-developed social networks. This is the case of the residents of the Niger Delta coastal communities, most of them claim to have been used to the menace of flooding despite the losses they incur during flood events. Social sources of resilience can include social networks; social security payments and lessons learned from past events (Nelson and Finan 2008). Resilience may not necessarily involve physical measures or spending significant funding, and can be attained through changes in awareness, procedure and management (Sivell et al. 2008). Resilient societies have individuals and networks which are both resilient (Diane, et'al, 2012). Economic resilience is concerned with business resilience for example, the nature of the business and its practices, flood defenses, transport utilities and how many businesses have climate adaptation strategies and insurance against extreme weather events (Sivell et al. 2008). To date community resilience has been difficult to accurately measure or quantify (McIntosh et al. 2008).

\section{Conclusion}

People are not willing to move to flood-free areas because of affordability and family ties; although they undertook some coping mechanisms but that does not necessarily make them resilient. Community coping mechanisms significantly reduces the impact of flooding on people; Level of income determine the kind of 
coping mechanisms; inadequate capacity to respond to flood management affects the resilience of affected communities

Early warning system is difficult to access. It has been observed that Climate change and climate variability are exacerbating the flooding problem. Thus, sustainable flood management provides the maximum possible social and economic resilience against flooding by protecting and working with the environment, in a way which is fair and affordable both now and in the future.

Finally, natural disaster crisis is often an endless crisis; People might be at risk for many years, decades or even centuries. Adapting to environmental change can involve adjustment in social, ecological, or economic systems in response to expected or observed changes in the environment as to mitigate adverse impacts. Therefore there is always a permanent need for surveillance, mitigation and continuous awareness to vulnerable communities/ societies.

\section{References}

[1]. Blaikie ,P. Cannon, T. Davis, I. and Wisner B. (199) At Risk: Natural Hazards,People's Vulnerability, and Disasters, Routledge, London.

[2]. Brilly, M and Polic, M (2005) Public perception of flood risks, flood forecasting and mitigation. Natural Hazards and Earth System Sciences 5:345-355

[3]. Burton I., Kates R.W., and White G.F.(1978) The Environment as Hazard, Oxford,University Press, New York

[4]. Burton I., Kates R.W., and White, G.F.(1993) The Environment as Hazard, Oxford,University Press, New York

[5]. Chukwu-Okeah, G O (2012) Flood in our Kitchen, nowhere to hide. Paper presented at the colloquium on 2012 flood in Nigeria. Danic Hotel, Port Harcourt.

[6]. Diane U. K, Armando, A, Shahbaz, M, David, K and Melanie, T(2012)

[7]. Resilience, Vulnerability and Adaptive Capacity of an Inland Rural Town Prone to Flooding: A Climate Change Adaptation Case Study of Charleville, Queensland, Australia. http://www.bom.gov.au/hydro/flood/qld/fld_reports/south_west_queensland_floods_2010.

[8]. Escobar, A (1999) 'After nature: Steps to an anti-essentialist political ecology', Current,Anthropology, 40(1):1-30.

[9]. Hillhorst, D. (2003) Complexity and Diversity: Unlocking Social Domains of Disaster,Responses, In Bankoff G., Frerks G., and Hillhorst D., (Editors), 2004

[10]. Mapping Vulnerability: Disasters, Development and People, Earthscan,London, p. 52-66.

[11]. Iyalla, T.M (2001)Environmental and Hydrogeological Mapping. A requirement for the Niger Delta Development Planning. Archive of the Nigerian Society of Engineers. Port Harcourt

[12]. McIntosh A, Stayner R, Carrington K, Rolley F, Scott J, Sorensen T (2008) Resilience in Rural Communities: Literature Review, Centre for Applied Research in Social Science. University of New England, Armidale

[13]. Mmom,P.C (2003) Niger Delta: A spatial Perspective to its Development. Zelon Ent. Port Harcourt.

[14]. Mmom,P.C (2010) Resilience and Sustainability in the face of Natural Hazards; a coping strategy for flood disaster. Technical paper presented at the Nigerian Environmental Society symposium on Flood in the Niger Delta. 23-24 ${ }^{\text {th }}$ September, 2010. Federal Secretariat complex, Port Harcourt.

[15]. Montz, B.E, Gruntfest, F (2002) Flash flood mitigation: recommendations for research and applications. Global Environmental Change Part B: Environmental Hazards 4(1):1-22

[16]. Nelson, D R, Finan, T.J (2008) Weak winters: Dynamic Decision-making and Extended Drought in Ceara, Northeast Brazil, in EC Jones \& AD Murphy (eds) The Political Economy of Hazards and Disasters. AltaMira Press, Walnut Creek, CA

[17]. Omofonmwan, S. I. and Odia, L. O. (2009). Oil Exploitation and Conflict in the Niger-Delta

[18]. Region of Nigeria. Kamla-Raj. Journal of Human Ecology 26(1): 25-30

[19]. Sivell, P.M, Reeves, S.J, Baldachin L, Brightman, T.G (2008) Client Project Report CPR117, Climate Change Resilience Indicators, TRL PPR 375. Prepared for South East England Regional Assembly, Transport Research Laboratory, Wokingham, Berkshire

[20]. Smith, K. (1992) Environmental Hazards: Assessing Risk and Reducing Disaster,Routledge, London.

[21]. Thanahathai, S ( 2008) Vulnerability and Resilience of the Bang Luang Community,to Flooding from the Chao Phraya River. Research Commons. The University of Waikato

[22]. Udo,R.K (1975) Geographical Regions of Nigeria. Heinemann. Ibadan

[23]. United Nations (2007) International Strategy for Disaster Reduction Hyogo Framework for Action 2005-2015: Building the Resilience of Nations and Communities to Disasters. United Nations, Geneva

[24]. Watts, M. (1983) Hazards, and Crises: a political economy of drought and famine in,Northern Nigeria, Antipode, 15: 24-34.

[25]. White, G.F.(1974) Natural Hazards: local, national global (eds.) Oxford University,Press, New York.

[26]. Wisner, B, Blaikie, P, Cannon T., and Davis I., 2004, "The challenge of disasters and,our approach", Chapter 1, In Wisner B., Blaikie P., Cannon T. and Davis L.,2004, At Risk: natural hazards, people's vulnerability, and disasters, $2^{\text {nd }}$, edition, Routledge, London. 